\title{
Przyczyny i polityczne skutki wyborów uzupełniających do Senatu RP
}

\begin{abstract}
Streszczenie: Wybory uzupełniające do Senatu RP w ocenie polskich polityków spełniają funkcję barometru odzwierciedlającego nastroje polityczne społeczeństwa. Celem artykułu jest wskazanie przyczyn i politycznych skutków wygasania mandatu senatora w trakcie kadencji. Porównując wyniki badań, uzyskane w rezultacie analizy zagadnienia określonego w tytule artykułu, podjęto próbę odpowiedzi na następujące pytania badawcze: 1) jakie czynniki wpływają na wygaśnięcie mandatu senatora w Polsce?; 2) jak kształtuje się frekwencja w tych wyborach na tle frekwencji w wyborach do Sejmu i Senatu?; 3) w jakim stopniu wybory uzupełniające do Senatu wpływają na zmianę jego kompozycji politycznej?; 4) czy stanowią one wiarygodny barometr nastrojów politycznych społeczeństwa? Zastosowane metody badawcze (instytucjonalno-prawna, statystyczna, porównawcza) pozwoliły sformułować wnioski. Dotychczas wygasło 44 mandaty senatorskie $(4,9 \%)$. Głównymi przyczynami były: śmierć $(36,4 \%)$, objęcie ważnych stanowisk publicznych $(22,8 \%)$ i wybór na posła do PE $(15,9 \%)$. Przeprowadzone 37 razy elekcje uzupełniające do Senatu z reguły wywoływały niewielkie zainteresowanie wyborców (najczęściej około 7\%). Jednak zdarzało się, że ich wyniki sygnalizowały nadchodzącą zmianę polityczną (elekcje uzupełniające w IV, V i VIII kadencji) lub kontynuację istniejącego układu politycznego (elekcje uzupełniające w VI kadencji). Skuteczność tego prognostyka jest dość zawodna; okazała się trafna w czterech z siedmiu kadencji Senatu.
\end{abstract}

Słowa kluczowe: Senat RP, wybory uzupełniające, wygaśnięcie mandatu, prognoza polityczna

$\mathbf{W}$ ybory uzupełniające to typ wyborów cząstkowych i jednocześnie wyborów przedterminowych, które odbywają się w następstwie wygaśnięcia mandatu jednego lub kilku reprezentantów organu przedstawicielskiego w trakcie kadencji.

Uzupełnienie składu organu przedstawicielskiego w trakcie kadencji, wskutek wygaśnięcia mandatu któregoś z jego członków, może odbyć się poprzez: 1) wybory uzupełniające, 2) powierzenie mandatu następnemu kandydatowi z listy, z której obsadzono mandat lub 3) obsadzenie mandatu przez zastępcę.

Wybory uzupełniające polegają na ponownym przeprowadzeniu procedury wyborczej tożsamej z tą, w której pierwotnie został obsadzony wygasły mandat. Głosowanie organizuje się wyłącznie w tym okręgu, w którym doszło do ustania mandatu. Powyższą metodę stosuje się do uzupełnienia składu organów wybieranych w wyborach większościowych. Z kolei powierzenie mandatu następnemu kandydatowi z listy, z której nastappiło obsadzenie mandatu odnosi się do wyborów proporcjonalnych. Natomiast obsadzenie mandatu przez zastępcę stanowi alternatywny sposób dla obsady mandatu przez kolejnego kandydata z listy. Zastępcami są osoby wybierane równocześnie z przedstawicielami w trakcie wyborów na wypadek wygaśnięcia mandatu przedstawiciela bądź niektórzy spośród kandydatów, którzy nie zdobyli w wyborach mandatów (Jagielski, 2013, s. 3, 88-90). 
W Polsce wybory uzupełniające dotyczą mandatu senatora i radnego w radzie gminy, który wygasł w trakcie trwania kadencji (Żukowski, 2012, s. 995-996). W wyniku elekcji nowy mandatariusz uzyskuje status członka organu przedstawicielskiego. Kadencja nowo wybranego mandatariusza trwa do momentu zakończenia kadencji organu przedstawicielskiego. Uzupełnianie składu Senatu w trakcie kadencji stanowi rezultat większościowego, a nie proporcjonalnego charakteru wyborów senackich oraz tego, że głosowanie odbywa się na osoby, a nie na listy (Grajewski, 2006, s. 14).

\section{Podstawy prawne wygaśnięcia mandatu senatora}

W czerwcu 1988 r. władze komunistyczne skierowały do opozycji solidarnościowej ofertę podjęcia rozmów przy „okragłym stole”. Przedstawiły koncepcję przywrócenia Senatu (Trembicka, 2003, s. 170). Idea powołania Senatu stanowiła efekt kalkulacji politycznej na to w jaki sposób dotychczas niezalegalizowana opozycja może zostać włączona do funkcjonującej struktury politycznej (Ciemniewski, 2010, s. 53). Ostatecznie o restytucji tej Izby przesądziły negocjacje prowadzone na początku marca $1989 \mathrm{r}$. w tzw. „grupie magdalenkowej” (Sokół, 2007, s. 209-210), w wyniku których PZPR zaaprobowała wolne i demokratyczne wybory do Senatu. W efekcie podjętych ustaleń wpisano instytucję Senatu do projektu Konstytucji PRL oraz projektu ustawy Ordynacja wyborcza do Senatu (Druk nr 470 i Druk nr 472 Sejm IX kad. 1989). Wskazano w nich, a właściwie podtrzymano kompromisowe rozstrzygnięcie „grupy magdalenkowej”, że Senat będzie wybierany w wyborach powszechnych, ale wówczas jeszcze nie zaproponowano wyborów uzupełniających do Senatu wskutek wygaśnięcia mandatu senatora w trakcie kadencji. Autorstwo tej koncepcji przypisuje się Bronisławowi Geremkowi (Dziubiński, 1990, s. 113), przedstawicielowi strony solidarnościowo-opozycyjnej przy „okragłym stole". Rozwiązania przyjętej wówczas ordynacji wyborczej do Senatu były, podobnie jak samo powołanie Izby, wynikiem przypadku, a nie przemyślanej wizji ustrojowej" (Orłowski, 2000, s. 198).

Regulacja z 1989 r. przewidywała, że w sytuacji nieobsadzenia lub wygaśnięcia mandatu senatora Izba druga parlamentu stwierdza wygaśnięcie mandatu senatora, a następnie podejmuje uchwałę w sprawie przeprowadzenia wyborów uzupełniających (Ustawa z dnia 7 kwietnia 1989 r. Ordynacja wyborcza ..., art. 15 ust. 2, art. 16). Pomimo tego, że przepis dotyczący wygaśnięcia mandatu senatora był kilkakrotnie nowelizowany w odniesieniu do przypadków, których wystapienie powoduje wygaśnięcie mandatu - o czym będzie dalej mowa, to wymóg stwierdzenia tego faktu przez Senat pozostawał niezmienny przez prawie dziesięć kolejnych lat, tj. do 31 maja 2001 r. Izba druga parlamentu, wraz z wejściem w życie postanowień nowej ordynacji wyborczej, utraciła kompetencję w zakresie stwierdzenia wygaśnięcia mandatu senatora oraz przeprowadzania wyborów uzupełniających.

Zgodnie $\mathrm{z}$ regulacjami zawartymi $\mathrm{w}$ przepisach wyborczych (zarówno $\mathrm{w}$ poprzednich, jak i obecnych) wygaśnięcie mandatu senatora następuje z mocy prawa, co stwierdza Marszałek Senatu w drodze postanowienia (Ustawa z dnia 12 kwietnia 2001 r. Ordynacja wyborcza ..., art. 214-215; Ustawa z dnia 5 stycznia 2011 r. Kodeks wyborczy..., art. $281 \S 1)$. W przypadku wygaśnięcia mandatu senatora wybory uzupełniające do 
Senatu zarządza Prezydent RP. Wybory uzupełniające są zarządzane i przeprowadzane $\mathrm{w}$ terminie trzech miesięcy od dnia stwierdzenia wygaśnięcia mandatu senatora. Takie elekcje nie są organizowane w okresie sześciu miesięcy przed dniem, w którym upływa termin zarządzenia wyborów do Sejmu (Ustawa z dnia 5 stycznia 2011 r. Kodeks wybor$c z y \ldots$, art. $283 \S 2$ ). Należy wskazać, że terminy dotyczące przeprowadzenia wyborów uzupełniających do Senatu zostały określone już w przepisach ordynacji z 1991 r. (Ustawa z dnia 10 maja 1991 r. Ordynacja wyborcza ..., art. 20).

Katalog przypadków powodujących wygaśnięcie mandatu senatora ulegał rozszerzeniu wraz z kolejnymi latami. Przepisy z 1989 r. określały, że wygaśnięcie mandatu senatora następuje wskutek: stwierdzenia nieważności wyboru senatora, odmowy złożenia ślubowania, utraty prawa wybieralności, śmierci, zrzeczenia się mandatu (Ustawa z dnia 7 kwietnia 1989 r. Ordynacja wyborcza ..., art. 15 ust. 1). W 1994 r. ustawodawca dookreślił, iż następuje ono także w związku z zajmowaniem przez senatora stanowiska lub powołania go na stanowisko: sędziego Trybunału Konstytucyjnego, sędziego Trybunału Stanu, Prezesa Narodowego Banku Polskiego, Rzecznika Praw Obywatelskich, Prezesa Najwyższej Izby Kontroli, ambasadora i wojewody (Ustawa z dnia 10 marca 1994 r. o zmianie ustawy - Ordynacja wyborcza ..., art. 19 ust. 1). W ten sposób doszło do przyjęcia jednolitej koncepcji rozstrzygania relacji mandat przedstawicielski - inne publiczne stanowisko lub funkcja (Żukowski, 2004, s. 168). W 1996 r. doprecyzowano, że uchylanie się senatora od złożenia ślubowania w terminie trzech miesięcy od pierwszego posiedzenia Senatu jest równoznaczne ze zrzeczeniem się mandatu (Ustawa z dnia 9 maja 1996 r. o wykonywaniu..., art. 2 ust. 4). Podobne rozstrzygnięcie wprowadziła także Ustawa zasadnicza, która zakazała łączenia mandatu senatora z: 1) wieloma godnościami publicznymi, tj. mandatem posła; 2) funkcjami: Prezesa Narodowego Banku Polskiego, Prezesa Najwyższej Izby Kontroli, Rzecznika Praw Obywatelskich, Rzecznika Praw Dziecka i ich zastępców, członka Rady Polityki Pieniężnej, członka Krajowej Rady Radiofonii i Telewizji, ambasadora oraz z zatrudnieniem w Kancelarii Sejmu, Kancelarii Senatu, Kancelarii Prezydenta RP lub z zatrudnieniem w administracji rządowej. Należy wskazać, że zakaz ten nie obejmował członków Rady Ministrów i sekretarzy stanu w administracji rządowej; 3) stanowiskami: sędziego, prokuratora, urzędnika służby cywilnej, żołnierza pozostającego w czynnej służbie wojskowej, funkcjonariusza policji oraz funkcjonariusza służb ochrony państwa (Konstytucja RP ..., art. 102, art. 103 ust. 1-2). W 2001 r. ustawodawca określił, iż wygaśnięcie mandatu senatora następuje: zarówno w wyniku zajmowania $\mathrm{w}$ dniu wyboru, jak i powołania w toku kadencji na stanowisko lub powierzenia funkcji, których, stosownie do przepisów Konstytucji RP, nie można łączyć ze sprawowaniem mandatu członka Izby drugiej parlamentu. Przyjęte wówczas przepisy stanowiły, że identyczny rezultat spowoduje sprawowanie albo objęcie przez senatora stanowisk lub funkcji w samorządzie terytorialnym m.in.: radnego, członka zarządu, wójta, burmistrza, prezydenta miasta (od 2002 r.) oraz pozbawienie mandatu prawomocnym orzeczeniem Trybunału Stanu (Ustawa z dnia 12 kwietnia 2001 r. Ordynacja wyborcza..., art. 213). Ustanie mandatu senatora mogło również wynikać ze złożenia niezgodnego z prawdą oświadczenia „lustracyjnego” określonego cztery lata wcześniej w przepisach ustawy (Ustawa z dnia 11 kwietnia 1997 o ujawnieniu..., art. 6 ust. 1). Nowo przyjęta ordynacja powtórzyła, za swoimi poprzedniczkami z roku 1989 i 1991, że wygaśnięcie mandatu jest konsekwencją: utraty prawa wybieral- 
ności, zrzeczenia się mandatu i śmierci (Ustawa z dnia 12 kwietnia 2001 r. Ordynacja wyborcza ..., art. 213). Przed pierwszymi wyborami do Parlamentu Europejskiego (PE) w Polsce ustawodawca wskazał, że wygaśnięcie mandatu senatora nastąpi w przypadku wyboru w toku kadencji na posła do PE (Ustawa z dnia 23 stycznia 2004 r. Ordynacja wyborcza..., art. 183 pkt 12).

Obecnie obowiązująca regulacja w zakresie prawa wyborczego potwierdziła powody wygaśnięcia mandatu senatora określone w powyższych przepisach (Ustawa z dnia 5 stycznia 2011 r. Kodeks wyborczy..., art. 279 § 1).

Wybory uzupełniające charakteryzują się istotnymi odrębnościami, a mianowicie: 1) głosowanie przeprowadza się wyłącznie na terytorium kraju; 2) prawo wybierania przysługuje tylko wyborcom stale zamieszkującym w okręgu, w którym wybory uzupełniające są przeprowadzane (Chmaj, Skrzydło, 2015, s. 134-135).

\section{Wygaśnięcie i obsadzanie mandatu senatora w trakcie kadencji}

Podczas ośmiu zakończonych i dziewiątej rozpoczętej (w listopadzie 2015 r.) kadencji Senatu utraciło ważność 44 z 934 mandatów senatorskich (4,9\%).

Pierwszą uchwałę w sprawie wyborów uzupełniających do Senatu podjęto już na 3. posiedzeniu. Bowiem tuż przed inauguracją działalności Izby zmarł wybrany na senatora Grzegorz Białkowski. Senat został więc zobligowany do uzupełnienia swojego składu (Porządek dzienny 3. posiedzenia Senatu PRL, 1989, s. 40).

Ostatnie jak dotąd zarządzenie wyborów uzupełniających do Senatu nastąpiło 28 grudnia 2015 r. (Postanowienie Prezydenta Rzeczypospolitej Polskiej z dnia 28 grudnia 2015 r.). Prezydent wydał je w związku z postanowieniem Marszałka Senatu (Postanowienie Marszałka Senatu Rzeczypospolitej Polskiej z dnia 9 grudnia 2015 r.) w sprawie wygaśnięcia mandatu senatora Bohdana Paszkowskiego, który został powołany na stanowisko wojewody podlaskiego.

Liczba wygaśnięć mandatów senatorskich w poszczególnych kadencjach przedstawia się następująco: cztery, zero, pięć, siedem, dziesięć, pięć, pięć, siedem, jeden.

Dotychczas tylko Senat II kadencji (1991-1993) rozpoczął i zakończył działalność w niezmienionym składzie. W Senacie IX kadencji wygasł jeden mandat. Jednak w sytuacji, gdy rozpoczęcie działalności Izby na czele z marszałkiem Stanisławem Karczewskim nastąiło dwa i pół roku temu, wydaje się o wiele bardziej zasadne wyłącznie przedstawienie stanu faktycznego, niż formułowanie jakichkolwiek wniosków w tym zakresie. W pozostałych siedmiu kadencjach Senatu liczba wygasłych mandatów wahała się od czterech do dziesięciu. Najczęściej, tj. trzykrotnie, ustawało w kadencji pięć mandatów. Miało to miejsce w Senacie III, VI i VII kadencji. Największa jak dotąd liczba wygaśnięć mandatów przypada na V kadencję Senatu, w której nastąpiła wymiana 10\% składu Izby.

Najczęstszą przyczyną przedterminowego zakończenia parlamentarnej działalności senatorów była śmierć. W analizowanym okresie nastąpiło 16 zgonów $(36,4 \%)$. Mandaty siedmiu senatorów wygasły w związku z wyborem na posłów do PE (15,9\%), a utrata jednego nastapiła wskutek wyboru na stanowisko komisarza UE $(2,3 \%)$. Powodem wygaśnięcia pięciu mandatów było objęcie ważnych funkcji publicznych określonych 
w art. 103 ust. 1 oraz 194 Konstytucji z 2 kwietnia 1997 r. (11,4\%). Pięciu mandatariuszy przedwcześnie zakończyło działalność w Senacie wskutek objęcia lub dalszego sprawowania funkcji w organach samorządu terytorialnego $(11,4 \%)$, a jeden w związku z nominacją na stanowisko wojewody (2,3\%). Przyczyną ustania trzech mandatów było złożenie niezgodnych z prawdą oświadczeń lustracyjnych (6,8\%). Sąd Najwyższy stwierdził nieważność wyboru dwóch senatorów i nakazał powtórzenie określonych czynności wyborczych $(4,5 \%)$. Dwa wygaśnięcia mandatów senatorskich nastapiło w związku z nominacją na stanowisko ambasadora $(4,5 \%)$. Wśród pozostałych powodów ustania mandatów było: objęcie stanowiska w delegaturze NIK $(2,3 \%)$ oraz rezygnacja bez podania przyczyny $2,3 \%$ ).

Senatorami, którzy zmarli w trakcie pełnienia funkcji w parlamencie byli: Jan J. Lipski, Edmund Osmańczyk, Adam Stanowski, Mieczysław Tarnowski, Tomasz Adamczuk, Romuald Jankowski, Henryk Rot, August Chełkowski, Jerzy E. Cieślak, Adam Graczyński, Krystyna Bochenek, Janina Fetlińska, Andrzej Mazurkiewicz, Stanisław Zając, Henryk Górski, Antoni Motyczka.

Określenie senator (łac. senex - starzec, stary człowiek), które jest związane z wiekiem, może wytwarzać przeświadczenie, że to właśnie zaawansowany wiek metrykalny stanowi główną przyczynę zgonów mandatariuszy Izby drugiej parlamentu. Jednak takie zapatrywanie nie znajduje potwierdzenia w rzeczywistości. Bowiem po 1989 r. średnia wieku senatorów w chwili śmierci wynosiła 60 lat $(60,4)$. Granice „trwania wieku dojrzałego" i „progu starości” mają w ocenie różnych nacji niezwykle subiektywny charakter. Polacy wyrazili przekonanie, że starość rozpoczyna się ok. 64 roku życia (Abrams, Vauclair, Swift, 2011, s. 26-27), tj. cztery lata po osiagnięciu przez kobiety i rok przed uzyskaniem przez mężczyzn wieku emerytalnego. Tylko sześciu senatorów w momencie śmierci ukończyło 64 rok życia (65 lat - trzech; 69 lat - jeden; 72 lata - jeden; 76 lat - jeden). Zgon trojga senatorów nie nastapił z przyczyn naturalnych tylko wskutek katastrofy lotniczej polskiego samolotu TU-154M pod Smoleńskiem 10 kwietnia $2010 \mathrm{r}$.

$\mathrm{W}$ gronie senatorów, których mandaty wygasły w związku z wyborem na posłów do PE znaleźli się: Adam Gierek, Genowefa Grabowska, Mieczysław Janowski, Grażyna Staniszewska, Ewa Tomaszewska, Beata Gosiewska, Bolesław Piecha. Obywatele naszego państwa wyrażają przekonanie, że elekcje do PE są ważne dla Polski jedynie w wymiarze wizerunkowym. Zdaniem prawie trzech czwartych respondentów CBOS (74\%), od tego, kto zasiada w Europarlamencie, zależy postrzeganie naszego kraju na arenie międzynarodowej (Komunikat z Badań CBOS, 2014, s. 4). Specyfika prawa wyborczego do PE powoduje, że, istotną rolę pełnią w wyborach «lokomotywy» wyborcze przyczyniając się do wzrostu frekwencji oraz rywalizacja między «liderami» poszczególnych list wyborczych, powodująca rozkład głosów na poszczególne listy" (Olszewski, 2010, s. 75). Nie dziwi więc fakt, że partie polityczne, wystawiają do PE już sprawdzonych kandydatów m.in. senatorów.

Wygaśnięcie mandatu Elżbiety Bieńkowskiej wynikało z nominacji na stanowisko Komisarza UE ds. Rynku Wewnętrznego i Usług, którą uzasadniano wieloletnią praktyką w zakresie zarządzania i wdrażania europejskich programów współfinansowanych z funduszy pomocowych i strukturalnych (IAR, PAP, 2015). Bowiem E. Bieńkowska w latach 2007-2013 zajmowała stanowiska Ministra Rozwoju Regionalnego oraz Ministra Infrastruktury i Rozwoju (Postanowienie Prezydenta RP z dnia 16 listopada 2007 r.; 
Postanowienie Prezydenta RP z dnia 18 listopada 2011 r.; Postanowienie Prezydenta RP z dnia 27 listopada 2013 r.).

Objęcie funkcji publicznych określonych w art. 103 ust. 1 i 194 Konstytucji z 2 kwietnia 1997 r. skutkowało wygaśnięciem pięciu kolejnych mandatów senatorskich. Zakończenie działalności parlamentarnej Leona Kieresa nastapiło w rezultacie powołania na stanowisko Prezesa Instytutu Pamięci Narodowej - Komisji Ścigania Zbrodni przeciwko Narodowi Polskiemu (IPN). Wygaśnięcie mandatów Ryszarda Słowińskiego i Piotra Boronia wynikało z wyboru do Krajowej Rady Radiofonii i Telewizji (KRRiT). Przedterminowe zakończenie senatorskiej działalności Mariana Nogi stanowiło konsekwencję powołania w skład Rady Polityki Pieniężnej (RPP). Natomiast do wygaśnięcia mandatu Adama Jamroza doszło wskutek wyboru na stanowisko sędziego Trybunału Konstytucyjnego (TK). Partie polityczne, które sprawują władzę w państwie powierzają ważne funkcje publiczne osobom $\mathrm{z}$ własnego zaplecza politycznego. Wśród nominowanych na kluczowe stanowiska państwowe, przez określone ugrupowania polityczne (AWS w 2000 r.; SLD w latach 2003 oraz 2004; PiS w 2007 r.), znaleźli się również senatorowie. Jednak nie wszystkie mandaty senatorskie musiały przedwcześnie wygasnać wskutek objęcia ważnych funkcji publicznych. Przykładowo, R. Sławiński został wybrany na stanowisko członka KRRiT dopiero w szóstej turze głosowania (Sprawozdanie stenograficzne Senat V kad. pos. 72, 2004, s. 52-76, 86-102). Oburzenie i kontrowersje wokół tej nominacji, także wśród kierownictwa politycznego Sojuszu, zostały zignorowane. Senator Zbigniew Kulak (SLD) oznajmił nonszalancko, że „każdy senator, zważywszy na zbliżający się koniec kadencji, ma prawo myśleć o swojej przyszłości” (Sygut, 2004, s. 36). Zatem partykularne interesy polityczne okazały się w tym przypadku ważniejsze niż kwalifikacje merytoryczne, a co za tym idzie dobro ogółu.

Senatorami, którzy utracili mandaty na rzecz członkostwa w określonych organach samorządu terytorialnego byli: Henryk Gołębiowski, Elżbieta Gelert, Piotr Głowski i Władysław Ortyl. Wyżej wymienieni mandatariusze objęli następujące funkcje: marszałka województwa, radnego, prezydenta miasta, marszałka województwa. Bogdan Zdrojewski zrezygnował z członkostwa w Izbie drugiej, na rzecz dalszego pełnienia stanowiska włodarza miasta Wrocławia, gdy TK orzekł, że funkcji prezydenta miasta nie można łączyć z mandatem senatora (Wyrok Trybunału Konstytucyjnego z dnia 11 stycznia 2000 r.). Jedynie E. Gelert ,zamieniła” mandat senatora na mandat radnego. Pozostali kandydaci objęli wyłącznie funkcje w organach wykonawczych samorządu terytorialnego. Natomiast Bohdan Paszkowski był pierwszym senatorem od 1989 r., który został wojewoda.

Złożenie niezgodnych z prawdą oświadczeń lustracyjnych skutkowało wygaśnięciem mandatów członków Senatu IV kadencji: Mariana Jurczyka (Obwieszczenie Prezesa Sądu Apelacyjnego w Warszawie z dnia 3 kwietnia 2000 r.; Obwieszczenie Prezesa Sądu Apelacyjnego w Warszawie z dnia 18 czerwca 2001 r.), Jerzego Mokrzyckiego (Obwieszczenie Prezesa Sądu Apelacyjnego w Warszawie z dnia 26 marca 2001 r.) i Zygmunta Ropelewskiego (Obwieszczenie Prezesa Sądu Apelacyjnego w Warszawie z dnia 23 maja 2001 r.). Mimo, że sąd uznał, że M. Jurczyk podjął współpracę z organami bezpieczeństwa państwa, działając pod przymusem w obawie utraty życia, to mandat utracił. Od tamtej pory żaden mandat senatora nie wygasł wskutek złożenia niezgodnego z prawdą oświadczenia lustracyjnego, ponieważ osoby ubiegające się o to pełnomocnic- 
two są zobowiązane do złożenia oświadczeń w przedmiocie pracy lub służby w organach bezpieczeństwa państwa lub współpracy z tymi organami w okresie od dnia 22 lipca 1944 r. do dnia 31 lipca 1990 r., tj. oświadczenie lustracyjne (Ustawa z dnia 11 kwietnia 1997 r. o ujawnieniu..., art. 7; Ustawa z dnia 18 października 2006 r. o ujawnianiu..., art. 4).

Złożenie z funkcji mandatariuszy Senatu VI kadencji Jarosława Laseckiego i Czesława Ryszki nastąpiło w wyniku stwierdzenia przez Sąd Najwyższy nieważności wyborów do Senatu Rzeczypospolitej przeprowadzonych w dniu 25 września 2005 r. w okręgu wyborczym nr 27 z siedzibą Okręgowej Komisji Wyborczej w Częstochowie. Sędziowie postanowili ponowić postępowanie wyborcze w części obejmującej czynności wyborcze od zarządzenia wydrukowania kart do głosowania z uwagi na to, że karty do głosowania były nieważne. „Na karcie do głosowania nie zostały bowiem zamieszczone nazwy lub skróty nazw komitetów wyborczych zgłaszających kandydatów na senatorów" (Uchwała Sądu Najwyższego z dnia 15 grudnia 2005 r.).

Powodem wygaśnięcia mandatów senatorów Ryszarda Czarnego i Marka Ziółkowskiego były nominacje na stanowiska ambasadorów. Rezygnacja Mariana Cichosza z zasiadania w Izbie drugiej parlamentu nastapiła wskutek objęcia przez niego funkcji dyrektora lubelskiej delegatury NIK. Bodo Engeling jako pierwszy i dotychczas jedyny senator III RP zrzekł się mandatu.

Dotychczas odbyło się 37 elekcji uzupełniających do Senatu odrodzonego w 1989 r. ${ }^{1}$ Liczba takich wyborów w kadencjach I-IX wynosiła odpowiednio: trzy, zero, cztery, pięć, dziesięć, trzy, pięć, sześć, jedna.

W związku ze zbliżającym się zakończeniem kadencji: I, III, IV, VI i VIII Senatu nie przeprowadzono ośmiu wyborów uzupełniających.

Mandat w wyborach uzupełniających do Senatu uzyskali: Piotr Ł. J. Andrzejewski, Jerzy Kłoczowski, Dorota Simonides, Piotr Miszczuk, Artur Balazs, Kazimierz Działocha, Stanisław Kochanowski, Adam Graczyński, Marian Noga, Zbigniew Zychowicz, Bogusław Litwiniec, Adam Rychliczek, Mirosław Lubiński, Krzysztof Jurgiel, Stanisław Huskowski, Ryszard Matusiak, Krystyna Bochenek, Kazimierz Jaworski, Wojciech Saługa, Zofia Skrzypek-Mrowiec, Klemens Ścierski, Elżbieta Streker-Dembińska, Jarosław Lasecki, Czesław Ryszka, Władysław Mańkut, Stanisław Zając, Michał Boszko, Leszek Piechota, Alicja Zając, Henryk Stokłosa, Czesław Ryszka, Jarosław Rusiecki, Maria Koc, Bolesław Piecha, Stanisław Pupa, Izabela Kloc, Anna M. Anders.

\section{Frekwencja w wyborach uzupełniających do Senatu na tle frekwencji w wyborach do Sejmu i Senatu}

W wyborach parlamentarnych w III RP najwyższą i najniższą frekwencję odnotowano w 1989 r. W pierwszej turze elekcji do Sejmu i Senatu, które odbyły się bezpośrednio

${ }^{1}$ Różnica pomiędzy liczbą wygasłych mandatów senatorskich (44) a liczbą nieprzeprowadzonych wyborów uzupełniających do Senatu z powodu zbliżającego się zakończenia kadencji Izby drugiej parlamentu (8) powinna wynosić 36 zamiast 37. Jednak w związku z tym, że przed zainaugurowaniem działalności przez Senat I kadencji, zmarł wybrany na senatora G. Białkowski, zaistniała konieczność uzupełnienia składu Izby drugiej parlamentu. 
po „okrągłym stole” wzięło udział $62 \%$ uprawnionych, zaś w drugiej zaledwie $25,5 \%$ (Codogni, 2012, s. 264, 297). Paradoksalnie ten najwyższy wskaźnik frekwencji w wyborach parlamentarnych w III RP był zarazem najniższym po II wojnie światowej (Dudek, 2002, s. 220-222), choć oczywiście poprzednie elekcje odbywały się na zupełnie innych zasadach. Jacek Raciborski, wskazując na szerszy kontekst tego zjawiska podkreśla, że w latach osiemdziesiątych XX w. nastąpiło zwiększenie płaszczyzny swobodnych politycznych zachowań obywateli. Jedną z form kontestacji władzy stała się absencja wyborcza. „Uczestnictwo w głosowaniu interpretowano jako akceptację władzy lub - co najmniej - jako wyraz konformizmu wobec niej. Absencja oznaczała natomiast kontestację systemu władzy bądź - co najmniej - wycofanie się z obcego świata polityki” (Raciborski, 1991, s. 113). Wybory parlamentarne przeprowadzone w latach: 1993, 2007 i 2015 zmotywowały do pójścia do urn nieco powyżej 50\% dorosłych Polaków, a mianowicie: $52,1 \%, 53,9 \%$ i 50,9\%. Natomiast w elekcjach do obu izb parlamentu, które odbyły się w latach: 1991, 1997, 2001, 2005 i 2011, brało udział od 40,6\% do 48,9\% uprawnionych obywateli, tj.: 43,2\%, 47,9\%, 46,3\%, 40,6\% oraz 48,9\% (Obwieszczenia PKW o wynikach wyborów..., 1989-2016). Wynik ten wskazuje, że w ponad połowie głosowań powszechnych do Sejmu i Senatu, przeprowadzonych w okresie 1991-2015, frekwencja wyborcza nie przekroczyła pułapu 50\%. Natomiast w wyborach w roku 1991 i 2005 nastapiło jej bardzo wyraźne ,załamanie”, wówczas zagłosowało tylko 43,2\%, a następnie $40,6 \%$ uprawnionych.

W okresie od 19 czerwca 1994 r. do 7 lutego 2011 r. przeprowadzono 32 razy wybory uzupełniające do Senatu ${ }^{2}$. W ponad połowie z nich, a konkretnie w 18 . frekwencja wyborcza nie przekroczyła 7\%. W dziewięciu elekcjach uzupełniających wahała się od 7,34\% do $17,11 \%$. W wyborach uzupełniajacych do Senatu przeprowadzonych razem z wyborami samorządowymi 19 czerwca $1994 \mathrm{r}$. osiagnęła poziom ponad 30\% (odpowiednio 31,66\% i $35,17 \%$ ). Natomiast w wyborach uzupełniających do Senatu połączonych z I tura przedterminowych wyborów prezydenckich 20 czerwca 2010 r. frekwencja wyborcza była rekordowa i wynosiła w poszczególnych okręgach: 47,07\%, 48,97\% i 53,47\%.

Przeprowadzona analiza dowiodła, że frekwencja wyborcza w wyborach uzupełniających do Senatu w Polsce jest bardzo niska. Dotychczas nigdy jeszcze, poza przypadkiem elekcji uzupełniającej do Senatu połączonej z wyborami prezydenckimi w 2010 r., nie osiagnęła nawet najniższej wartości uzyskanej w wyborach przeprowadzanych równocześnie do obu izb parlamentu.

\section{Polityczne skutki wyborów uzupełniających do Senatu odrodzonego w 1989 r.}

Wybory uzupełniające do Senatu wpływały również na zmianę kompozycji politycznej Senatu (Leszczyńska, 2015, s. 158-170). W Senacie I kadencji zarówno nowo wybrani mandatariusze, jak ich poprzednicy byli reprezentantami „Solidarności”. Natomiast w wyniku wyborów uzupełniających do Senatu przeprowadzanych w kolejnych kadencjach wahadło polityczne zmieniało płaszczyznę. W Senacie III kadencji mandat straciło Polskie Stronnictwo Ludowe (PSL) na rzecz Stronnictwa Ludowo-Chrześcijańskiego (SLCh). dencji.

${ }^{2}$ Brak danych o frekwencji w wyborach uzupełniających przeprowadzonych w Senacie I ka- 
W związku z tym, że SLD odzyskał trzy utracone wówczas mandaty senatorskie, to jego wpływy polityczne w Izbie drugiej parlamentu pozostały niezmienne. W IV kadencji Senatu cztery wakujące mandaty po przedstawicielu AWS i kandydatach formalnie niezależnych, ale związanych z nurtem „Solidarności”, obsadzili reprezentanci SLD. Natomiast ludowcy zachowali wówczas ciągłość polityczną. Zmiana alokacji preferencji wyborczych wskazywała, że lewica ma szanse na przejęcie władzy jesienią $2001 \mathrm{r}$.

Wybory, które odbyły się w trakcie V kadencji Senatu zmieniły polityczną kompozycję Izby. Socjaldemokraci z trudem zdołali zachować tylko dwa z ośmiu wygasłych mandatów. Niewielką różnicą głosów (odpowiednio 874 głosów i 702 głosy) Sojusz wywalczył z Ligą Polskich Rodzin (LPR) wakujące miejsca w Senacie. Natomiast sześć mandatów zwolnionych przez senatorów SLD zdobyli kandydaci: Platformy Obywatelskiej (PO) - dwa, Prawa i Sprawiedliwości (PiS) - jeden, LPR - jeden, Unii Wolności (UW) - dwa. W wyborach uzupełniających do Senatu UW straciła wprawdzie jeden mandat (na rzecz LPR), ale zdobyła dwa nowe. Natomiast wakujący po przedstawicielu AWS mandat objął członek NSZZ „Solidarność”. Zarówno poprzednik jak i jego następca należeli do tego samego ruchu katolików świeckich - Akcji Katolickiej. Głęboki kryzys zaufania do rządów lewicowych w Polsce spowodował, że preferencje wyborcze znowu zaczęły zmieniać swoje alokacje. Wyniki kolejnych elekcji wskazywały tym razem, że sympatia elektoratu zdecydowanie przesuwa się ,w prawą stronę”. Wprawdzie dwojgu lewicowym senatorom: G. Grabowskiej i E. Gierkowi udało się wygrać wybory do PE, ale socjaldemokraci nie zdołali już wywalczyć zwolnionych przez nich miejsc w Izbie drugiej parlamentu. Wybory uzupełniające do Senatu VI kadencji wpłynęły na zmianę politycznej konfiguracji. Opróżniony przez reprezentantkę PO fotel w Izbie drugiej izbie parlamentu zdobył kandydat z ramienia Koalicyjnego Komitetu Wyborczego Lewica i Demokraci SLD+SdPL+PD+UP. Niewątpliwie sukces członka Sojuszu w tej elekcji wynikał z pragmatyzmu politycznego popierających go ugrupowań politycznych w postaci wspólnej listy Lewicy i Demokratów.

Elekcja uzupełniająca do Senatu VII kadencji miała skutki polityczne. W jej następstwie zarówno PO, jak i PiS utraciły po jednym mandacie na rzecz przedstawiciela PSL oraz kandydata bezpartyjnego.

W trakcie funkcjonowania Senatu VIII kadencji sześciokrotnie przeprowadzano elekcje uzupełniające do Senatu, które wygrało ugrupowanie Jarosława Kaczyńskiego. Kandydaci PiS nie tylko zdołali obsadzić wakujące mandaty po czterech swoich partyjnych kolegach, ale także po dwóch reprezentantach PO.

Wybory, które zorganizowano w celu uzupełnienia składu Senatu IX kadencji, nie wpłynęły na zmianę politycznej konfiguracji w Izbie drugiej parlamentu. Reprezentantka PiS zdobyła mandat zwolniony przez przedstawiciela tego ugrupowania.

\section{Podsumowanie}

W Senacie odrodzonym w roku 1989 jak na razie wygasło 44 z 934 mandatów (4,9\%). Głównymi przyczynami przedterminowego zakończenia parlamentarnej działalności senatorów były: śmierć $(36,4 \%)$, objęcie ważnych stanowisk publicznych $(22,8 \%)$ i wybór na posła do PE $(15,9 \%)$. 
Mimo, że wybory uzupełniające do Senatu RP zazwyczaj wzbudzają niewielkie zainteresowanie wśród wyborców, to ugrupowania polityczne są nimi bardzo mocno zainteresowane (Sarnecki, 1999, s. 23) i za wszelką cenę starają się zdobyć lub utrzymać wakujący mandat. Wielu polskich polityków traktuje je jak barometr wskazujący stan aktualnych nastrojów politycznych w społeczeństwie „To będzie takie mierzenie temperatury poparcia" - powiedział J. Kaczyński, promując kandydaturę Anny M. Anders na senatora (Jarosław Kaczyński, 2016). Zdarzało się oczywiście, że wyniki wyborów uzupełniających do Senatu RP sygnalizowały nadchodzącą zmianę polityczną (elekcje uzupełniające w IV, V i VIII kadencji) lub wskazywały na kontynuację istniejącego układu politycznego (elekcje uzupełniające w VI kadencji). Generalnie jednak ten prognostyk jest dość zawodny. Dotychczas okazał się trafny w czterech z siedmiu zakończonych kadencji Senatu ${ }^{3}$. Natomiast nakłady pieniężne na przeprowadzenie takich elekcji są bardzo wysokie. Przykładowo, z informacji Krajowego Biura Wyborczego (KBW) wynika, że koszt wyborów uzupełniających do Senatu RP w średniej wielkości okręgu wyborczym w 2014 r. wynosił 700-800 tys. zł, natomiast w największych okręgach wyborczych sięgał nawet dwóch mln $\mathrm{z}^{4}$. Rozwiązanie tej kwestii wydaje się więc interesujące. Ordynacja wyborcza do Senatu z 1935 r. (Ustawa z dnia 8 lipca 1935 r. Ordynacja wyborcza ..., art. 46) przewidywała zastępców, którzy uzyskiwali mandat w razie wygaśnięcia lub utraty mandatu przez senatora. W sytuacji, gdy senator nie posiadał już zastępcy, mandat mógł pozostać nieobsadzony do końca kadencji. Obecnie we Francji kandydaci na senatorów wskazują swoich oficjalnych zastępców w sytuacji rezygnacji lub śmierci (Konstytucja Republiki Francuskiej, art. 25). Należy jednak zaznaczyć, że w obu wyżej wymienionych przypadkach, tj. w Polsce (1935-1939) oraz obecnie we Francji wybory do Senatu nie były i nie są powszechne.

Organizowanie wyborów uzupełniających do Senatu RP razem z wyborami samorządowymi i prezydenckimi skutkowało zdecydowanym wzrostem frekwencji z kilku lub kilkunastu do kilkudziesięciu procent. Z reguły odsetek głosujących w elekcjach uzupełniających do Senatu wynosił co najwyżej 7\%. Natomiast, gdy takie wybory odbywały się w tym samym terminie co samorządowe lub prezydenckie, to frekwencja wzrastała powyżej 30\% (w przypadku wyborów samorządowych) oraz ponad $40 \%$, a nawet 50\% (w przypadku wyborów prezydenckich). Jednak możliwość zorganizowania takich elekcji w jednym terminie zdarza się okazjonalnie.

\section{Bibliografia}

\section{Akty prawne i orzecznictwo:}

Konstytucja Rzeczypospolitej Polskiej z 2 kwietnia 1997 r., Dz. U. Nr 78, poz. 483.

Konstytucja Republiki Francuskiej z dnia 4 października 1958 r., Wydawnictwo Sejmowe, Warszawa. Ustawa z dnia 8 lipca 1935 r. Ordynacja wyborcza do Senatu, Dz. U. Nr 47, poz. 320.

Ustawa z dnia 7 kwietnia 1989 r. Ordynacja wyborcza do Senatu Polskiej Rzeczypospolitej Ludowej, Dz. U. Nr 19, poz. 103.

${ }^{3}$ W Senacie II kadencji nie wygasł żaden mandat. Natomiast Senat IX kontynuuje działalność zapoczątkowaną po wyborach $2015 \mathrm{r}$.

${ }^{4}$ Koszt wyborów uzupełniających do Senatu RP ZPOW-066-929/14 - na podstawie informacji udzielonej przez Janusza Płochockiego, głównego specjalisty w KBW. 
Ustawa z dnia 10 maja 1991 r. Ordynacja wyborcza do Senatu Rzeczypospolitej Polskiej, Dz. U. Nr 58, poz. 246.

Ustawa z dnia 10 marca 1994 r. o zmianie ustawy - Ordynacja wyborcza do Senatu Rzeczypospolitej Polskiej, Dz. U. Nr 43, poz. 164.

Ustawa z dnia 9 maja 1996 r. o wykonywaniu mandatu posta i senatora, Dz. U. Nr 67, poz. 350.

Ustawa z dnia 11 kwietnia 1997 r. o ujawnieniu pracy lub stużby w organach bezpieczeństwa państwa lub wspótpracy z nimi w latach 1944-1990 osób petniqcych funkcje publiczne, Dz. U. Nr 70, poz. 443.

Ustawa z dnia 12 kwietnia 2001 r. Ordynacja wyborcza do Sejmu Rzeczypospolitej Polskiej i do Senatu Rzeczypospolitej Polskiej, Dz. U. Nr 46, poz. 499.

Ustawa z dnia 23 stycznia 2004 r. Ordynacja wyborcza do Parlamentu Europejskiego, Dz. U. Nr 25, poz. 219.

Ustawa z dnia 18 października 2006 r. o ujawnianiu informacji o dokumentach organów bezpieczeństwa państwa z lat 1944-1990 oraz treści tych dokumentów, Dz. U. 2013, poz. 1388.

Ustawa z dnia 5 stycznia 2011 r. Kodeks wyborczy, Dz. U. Nr 21, poz. 112.

Uchwała Sądu Najwyższego z dnia 15 grudnia 2005 r. w sprawie ważności wyborów do Sejmu Rzeczypospolitej Polskiej i do Senatu Rzeczypospolitej Polskiej przeprowadzonych w dniu 25 września 2005 r., Sygn. Akt III SW 199-200/05, Dz. U. Nr 248, poz. 2097.

Wyrok Trybunału Konstytucyjnego z dnia 11 stycznia 2000 r., Sygn. K. 7/99, Dz. U. Nr 3, poz. 45.

Obwieszczenie Prezesa Sądu Apelacyjnego w Warszawie z dnia 3 kwietnia 2000 r. o podaniu do publicznej wiadomości prawomocnych orzeczeń Sqdu stwierdzajacych niezgodność z prawda oświadczeń osób lustrowanych, M. P. Nr 11, poz. 236.

Obwieszczenie Prezesa Sądu Apelacyjnego w Warszawie z dnia 18 czerwca 2001 r. o podaniu do publicznej wiadomości prawomocnego orzeczenia Sadu stwierdzajacego niezgodność z prawda oświadczenia osoby lustrowanej, M. P. Nr 20, poz. 326.

Obwieszczenie Prezesa Sądu Apelacyjnego w Warszawie z dnia 26 marca 2001 r. o podaniu do publicznej wiadomości prawomocnego orzeczenia Sąu stwierdzajacego niezgodność z prawda oświadczenia osoby lustrowanej, M. P. Nr 10, poz. 165.

Obwieszczenie Prezesa Sądu Apelacyjnego w Warszawie z dnia 23 maja 2001 r. o podaniu do publicznej wiadomości prawomocnego orzeczenia Sadu stwierdzajacego niezgodność z prawda oświadczenia osoby lustrowanej, M. P. Nr 17, poz. 297.

Postanowienie Prezydenta RP z dnia 16 listopada 2007 r. o powołaniu w skład Rady Ministrów, M. P. $\mathrm{Nr} 85$, poz. 947.

Postanowienie Prezydenta RP z dnia 18 listopada 2011 r. o powołaniu w skład Rady Ministrów, M. P. Nr 102, poz. 1027.

Postanowienie Prezydenta RP z dnia 27 listopada 2013 r. o zmianie w składzie Rady Ministrów, M. P. 2013, poz. 1005.

Postanowienie Prezydenta Rzeczypospolitej Polskiej z dnia 28 grudnia 2015 r. w sprawie zarzqdzenia wyborów uzupetniajacych do Senatu Rzeczypospolitej Polskiej, Dz. U. 2016, poz. 4.

Postanowienie Marszałka Senatu Rzeczypospolitej Polskiej z dnia 9 grudnia 2015 r. w sprawie stwierdzenia wygaśnięcia mandatu senatora Bohdana Paszkowskiego, Dz. U. 2015, poz. 1297.

\section{Dokumenty:}

Inter-Parliamentary Union, http://archive.ipu.org/parline-e/parlinesearch.asp, 10.0.2018.

Obwieszczenia Państwowej Komisji Wyborczej (PKW) o wynikach wyborów do Sejmu RP i Senatu $R P$ w latach 1991-2015 oraz wynikach wyborów uzupetniajacych do Senatu PRL w 1989 r. i Senatu RP w latach 1990-2016. 
Porzqdek dzienny 3. posiedzenia Senatu PRL w dniach 28, 29, 31 lipca i 1 sierpnia 1989 r. (1991), w: Wybrane dane o pracy Senatu Rzeczypospolitej Polskiej I kadencji, Wydawnictwo Kancelarii Senatu, Warszawa.

Sejm IX kadencji, Druk nr 470, 15 marca 1989 r. (1989), Sejm PRL, Warszawa.

Sejm IX kadencji, Druk nr 472, 15 marca 1989 r. (1989), Sejm PRL, Warszawa.

Sprawozdanie stenograficzne z 72 posiedzenia Senatu w dniach 17-18 listopada 2004 r., (2004), Senat RP, Warszawa.

Wybory do Parlamentu Europejskiego w powyborczych deklaracjach Polaków (2014), BS/96/214, Komunikat z Badań CBOS, Warszawa.

\section{Artykuły i opracowania naukowe:}

Abrams D., Vauclair Ch.-M., Swift H., Predictors of attitudes to age across Europe, Centre for the Study of Group Processes, University of Kent on behalf of Department for Work and Pensions, http://research.dwp.gov.uk.asd/asd5/rports2011-2012/rrep735.pdf, 25.11.2012.

Ciemniewski J. (2010), Dwuizbowość w systemie konstytucyjnym III Rzeczypospolitej, „Przegląd Sejmowy", $\mathrm{nr} 5$.

Chmaj M., Skrzydło W. (2015), System wyborczy w Rzeczypospolitej Polskiej, Wydawnictwo Lex a Wolters Kluwer business, Warszawa.

Codogni P. (2012), Wybory czerwcowe 1989 roku, Wydawnictwo Instytut Pamięci Narodowej, Komisja Ścigania Zbrodni przeciwko Narodowi Polskiemu, Warszawa.

Dudek A. (2002), Pierwsze lata III Rzeczypospolitej (1989-2001), Wydawnictwo Arcana, Kraków.

Dziubiński K. (1990), Magdalenka. Transakcja epoki. Notatki z poufnych spotkań Kiszczak-Watęsa, Wydawnictwo SYLWA, Warszawa.

Grajewski K. (2006), Status prawny posta i senatora, Wydawnictwo Sejmowe, Warszawa.

Jagielski M. (2013), Prawo wyborcze - wersja $\beta$, Kancelaria Senatu RP, Warszawa.

Leszczyńska K. (2015), Senat Rzeczypospolitej Polskiej w latach 1989-2011, Wydawnictwo UMCS, Lublin.

Olszewski E. (2010), Polacy w wyborach do Parlamentu Europejskiego w 2009 roku, w: Rzeczpospolita Polska 1989-2009. Problemy wybrane, red. K. Leszczyńska, Wydawnictwo Adam Marszałek, Toruń.

Orłowski W. (2000), W sprawie nowego prawa wyborczego do Senatu, w: Konstytucyjny ustrój państwa. Księga jubileuszowa Profesora Wiesława Skrzydty, Wydawnictwo UMCS, Lublin.

Raciborski J. (1991), Zachowania wyborcze Polaków w warunkach zmiany systemu politycznego, w: Wybory i narodziny demokracji w krajach Europy Środkowej i Wschodniej, red. J. Raciborski, Wydawnictwo Instytut Socjologii UW, Warszawa.

Sarnecki P. (1999), Senat RP a Sejm i Zgromadzenie Narodowe, Wydawnictwo Sejmowe, Warszawa.

Sokół W. (2007), Geneza i ewolucja systemów wyborczych w państwach Europy Środkowej i Wschodniej, Wydawnictwo UMCS, Lublin.

Trembicka K. (2003), Okragły stól w Polsce. Studium o porozumieniu politycznym, Wydawnictwo UMCS, Lublin.

Żukowski A. (2004), System wyborczy do Sejmu i Senatu RP, Wydawnictwo Sejmowe, Warszawa.

Żukowski A. (2012), Wybory uzupetniajace, w: Encyklopedia politologii, red. M. Żmigrodzkiego, tom II: Instytucje i systemy polityczne, red. B. Dziemidok-Olszewska, W. Sokół, Wydawnictwo a Wolters Kluwer business, Warszawa.

\section{Artykuly prasowe i internetowe:}

IAR, PAP, Elżbieta Bieńkowska komisarzem Unii w trzech dziedzinach, Polskie Radio PL, Portal Polskiego Radia S.A., https://www.polskieradio.pl/42/273/Artykul/1229291, 2.01.2015. 
Jarosław Kaczyński w Suwatkach, 20.02.2016, https://radio5.com.pl/jaroslaw-kaczynski-w-suwalkach, 21.02.2016.

Sygut T. (2004), Tajemnice Senatu. Tylko jawne głosowanie może zlikwidować senackq sitwę, „Przegląd”, nr 49.

\title{
Reasons and political consequences of by-elections to the Polish Senate
}

\begin{abstract}
Summary
In the opinion of Polish politicians, by-elections to the Senate of the Republic of Poland have a barometer function, reflecting the political climate in the society. The objective of the present article is to indicate the reasons for and political consequences of mid-term expiry of senators' mandates. In comparing the research results obtained by analyzing the topic of this article we attempted to answer the following research questions: 1) what factors influence the expiry of senators' mandates in Poland?; 2) what is voter turnout in these elections, when compared to the ordinary elections to the Polish parliament (Sejm and Senate)? 3) to what extent do the by-elections to the Senate influence the change in its political composition?; 4) do they form a credible barometer of the political climate in the society?

The research methods applied (institutional-legal, statistical, and comparative) allowed us to formulate our conclusion. So far, 44 senators' mandates $(4.9 \%)$ have expired. The main reasons for that have been death (36.4\%), appointment to high public offices $(22.8 \%)$, or being elected EMP $(15.9 \%)$. The Senate by-elections have been conducted 37 times, and they have usually generated limited interest of voters (usually around 7\%). Nevertheless, in several cases their results signalled the upcoming political change (by-elections in the IV, V and VIII terms) or the continuation of the existing political arrangement (by-elections in the VI term of office). The general efficiency of this forecast is rather elusive; it turned out to be correct in four out of seven terms of Senate.
\end{abstract}

Key words: Senate of the Republic of Poland, by-elections, expiry of mandate, political forecast 
